\title{
Venlafaxine-induced acute dystonia
}

\author{
Venlafaksin kullanımı ile ilişkili akut distoni
}

\author{
Mehmet Hamdi Örüm ${ }^{1}$ (D) Yaşar Kapıcı ${ }^{2}$ (D) \\ ${ }^{1}$ Department of Psychiatry, Kahta State Hospital, Adryaman, Turkey \\ ${ }^{2}$ Department of Psychiatry, Adiyaman University, Faculty of Medicine, Adiyaman, Turkey
}

\begin{abstract}
Venlafaxine is an antidepressant which can cause side effects such as dry mouth, decreased libido, nausea, constipation, dizziness, headache, and diaphoresis. Dystonia is another rare side effect of venlafaxine which may cause serious complications. In this case report, we present the treatment process of a female patient who developed acute dystonia due to venlafaxine use. This unusual side effect may lead to noncompliance to treatment. Dystonia should be investigated in patients using venlafaxine.
\end{abstract}

Keywords: Antidepressant, dystonia, side effect, venlafaxine.

ÖZ

Venlafaksin ağız kuruluğu, cinsel isteksizlik, mide bulantısı, kabızlık, baş dönmesi, baş ağrısı ve terleme gibi yan etkilere neden olabilen bir antidepresandır. Distoni, venlafaksinin nadir görülen başka bir yan etkisi olup ciddi komplikasyonlara neden olabilir. Burada, venlafaksin kullanımı nedeniyle akut distoni gelişen bir kadın hastanın tedavi süreci sunuldu. Bu nadir yan etki tedaviye uyumsuzluğuna neden olabilir. Venlafaksin kullanan hastalarda distoni sorgulanmalıdır.

Anahtar sözcükler: Antidepresan, distoni, yan etki, venlafaksin.

Venlafaxine is an antidepressant of a group of drugs called selective serotonin and norepinephrine reuptake inhibitors (SSNRIs) which are used to treat major depressive disorder (MDD), generalized anxiety disorder (GAD), and panic disorder. Commonly reported side effects of venlafaxine include dry mouth, decreased libido, nausea, constipation, dizziness, drowsiness, headache, and diaphoresis. ${ }^{[1-3]}$ Dystonia associated with venlafaxine use has been reported but is very rare. ${ }^{[2]}$ In this case report, we discuss the treatment process of a female patient who developed dystonia due to venlafaxine use.

\section{CASE REPORT}

A 44-year-old, married, unemployed, female patient admitted to our outpatient clinic. She had been followed up with diagnosis of MDD at different psychiatry outpatient clinics for 10 years and had history of three suicide attempts via selfpoisoning. The patient had been using per-oral (PO) citalopram $40 \mathrm{mg} /$ day for a year prescribed at our outpatient clinic and had stopped using her medication two weeks ago. Her depressive symptoms of fatigue, worthlessness, pessimism, insomnia, irritability, restlessness, and loss

Received: May 23, 2019 Accepted: July 16, 2019 Published online: October 31, 2019

Correspondence: Mehmet Hamdi Örüm, MD. Kahta Devlet Hastanesi Psikiyatri Kliniği, 02100 Kahta, Adıyaman, Türkiye. Tel: +90 538 - 2207558 e-mail: mhorum@hotmail.com 
of libido were not taken under control with this treatment. She was hospitalized with the diagnosis of MDD according to Diagnostic and Statistical Manual of Mental Disorders, Fifth Edition (DSM-V). ${ }^{[4]}$ Previously prescribed drugs used by the patient at the effective dose and time included sertraline, duloxetine, olanzapine, supride, fluoxetine, paroxetine, quetiapine, and alprazolam. Venlafaxine $75 \mathrm{mg} /$ day was initiated for depressive symptoms and lorazepam $2.5 \mathrm{mg} /$ day for insomnia. The patient and her relatives were informed about the effects and possible side effects of the treatment. The patient's initial baseline laboratory results at the time of admission were unremarkable. Twenty-four hours after venlafaxine intake and 12 hours after lorazepam intake, the patient developed dystonia in the neck, and difficulty and pain when facing right. The patient's thyroid, renal, and liver function tests were within normal limits. History of alcohol and substance abuse was unavailable. The patient had a smoking history of 10 packs/year. Her mother had history of MDD and her sister generalized anxiety disorder. Since lorazepam can be used in the treatment of dystonia, the patient's new onset of dystonia was attributed to venlafaxine which was discontinued. Intramuscular (IM) biperiden $5 \mathrm{mg} / \mathrm{mL}$ twice daily was added to the treatment. The dystonia gradually disappeared 45 minutes after biperiden injection. No dystonia was observed until PO lorazepam and IM biperiden were administered. Bupropion extended-release (XL) $150 \mathrm{mg} /$ day was initiated 24 hours after discontinuation of venlafaxine. No similar side effects were reported during the follow-up of the patient. After bupropion XL was increased to $300 \mathrm{mg} /$ day, the patient's psychiatric symptoms significantly improved. The patient and her relatives were warned of edema due to venlafaxine use and their informed consent was obtained. The patient's Naranjo Adverse Dug Reaction Probability Scale (NADRPS) score was 6. ${ }^{[5]}$

\section{DISCUSSION}

The patient was evaluated as a case of venlafaxine-induced dystonia. There was a temporal relationship between initiation of venlafaxine and side effect of dystonia, which completely cured after discontinuation of the drug. In addition, other examinations were normal. The NADRPS score indicates a likely association between drug use and dystonia. ${ }^{[5]}$ We can therefore assume the side effect was very likely induced by venlafaxine. Dystonia is a movement disorder that causes involuntary contractions of muscles. These contractions result in twisting and repetitive movements which are sometimes painful. ${ }^{[6]}$ Fonseca et al. ${ }^{[7]}$ reported a case of venlafaxine-induced dystonia in a 29-year-old female patient who was managed for a diagnosis of MDD. Two hours after taking the medication, dystonia in the tongue and cervical torsion were observed; the adverse effect resolved after adding biperiden. Several patients with history of venlafaxine-induced akathisia have been reported, with ages of 33, 40, 53, and 69; three of these patients had concurrent physical disease and polypharmacy use. $^{[2]}$ Sonmez and Kosger ${ }^{[2]}$ reported a young patient with venlafaxine-induced dystonia with no physical disease or use of other medicines. The underlying mechanism of venlafaxineinduced dystonia has not been fully elucidated. Lane ${ }^{[8]}$ reported that the inhibitory effects of serotonergic and noradrenergic neurons that stimulate the ventral tegmental area may play an important role in dopamine transmission. This could explain SSRI and venlafaxineinduced akathisia. Venlafaxine is metabolized by CYP2D6. As Preskorn et al. ${ }^{[9]}$ reported high plasma concentration of the drug after the use of slow-release venlafaxine, in people with CYP2D6 polymorphism who were slow metabolizers. Another study demonstrated that cytochrome P450 enzyme and polymorphisms of the serotonin-dopamine transporter and receptor play a significant role in the development of extrapyramidal symptoms in SSRI users. ${ }^{[2]}$ The P450 enzyme system and polymorphisms of the serotonin-dopamine transporter and receptor, studied in recent years, may also be factors that contributed to the development of dystonia in our case. When dystonia occurs, the patient's general medical condition should be reassessed and other organic conditions that may cause dystonia should be ruled out. Dosage can be reduced or the drug can be switched. ${ }^{[10]}$ Biperiden or/and lorazepam can be added to the treatment. In our patient, occurrence of dystonia during the use of lorazepam suggested that the side effect may have been more severe had lorazepam not been used. In our patient, when the drug 
was discontinued and biperiden was added, the dystonia resolved. The World Health Organization defines 'probable' as an event or laboratory test abnormality, with reasonable time relationship to drug intake. ${ }^{[11]}$ Factors influencing patient compliance to medical treatment in psychiatric disorders include patient-related influences, physician-related variables, factors related to the patient's environment, treatment-related factors, and side effects. The influence of side effects in patient compliance to treatment has been demonstrated. Sometimes, patients continue to use the drug despite side effects. Relatives of the patient, and additional psychiatric and medical diseases should also be taken into consideration. ${ }^{[12-15]}$ Therefore the patient and relatives were warned about possible side effects.

In conclusion, this case report suggests that physicians, patients, and relatives should be aware that venlafaxine may induce dystonia, negatively affecting quality of life and compliance to treatment. Further systemic research should be conducted on venlafaxine-associated dystonia to provide a greater understanding of both its prevalence and etiology.

\section{Declaration of conflicting interests}

The authors declared no conflicts of interest with respect to the authorship and/or publication of this article.

\section{Funding}

The authors received no financial support for the research and/or authorship of this article.

\section{REFERENCES}

1. Schoretsanitis G, Haen E, Hiemke C, Fay B, Unholzer $\mathrm{S}$, Correll $\mathrm{CU}$, et al. Sex and body weight are major determinants of venlafaxine pharmacokinetics. Int Clin Psychopharmacol 2018;33:322-9.

2. Sonmez I, Kosger F. Venlafaxine-induced acute dystonia: A case report. Dusunen Adam The Journal of Psychiatry and Neurological Sciences 2015;28:374-7.
3. Örüm $\mathrm{MH}$, Kara MZ, Eğilmez OB. Venlafaksin ve paroksetin kullanımına bağlı, orgazm olmaksızın idrar sonrasında ortaya çıkan spontan ejakülasyonlar: Bir olgu sunumu. Kırıkkale Üniversitesi Tip Fakültesi Dergisi 2018;20:349-52.

4. American Psychiatric Association. Diagnostic and Statistical Manual of Mental Disorders (DSM-5). 5th ed. Washington: 2013.

5. Kose S, Akin E, Cetin M. Adverse drug reactions and causality: the Turkish version of Naranjo Adverse Drug Reactions Probability Scale. Psychiatry and Clinical Psychopharmacology 2017;27:205-6.

6. Stone J, Hoeritzauer I, Tesolin L, Carson A. Functional movement disorders of the face: A historical review and case series. J Neurol Sci 2018;395:35-40.

7. Fonseca L, Rodrigues M, Machado A. Psychogenic movement disorder after a venlafaxine-induced dystonia. Mov Disord 2010;25:506-7.

8. Lane RM. SSRI-induced extrapyramidal sideeffects and akathisia: implications for treatment. J Psychopharmacol 1998;12:192-214.

9. Preskorn S, Patroneva A, Silman H, Jiang $\mathrm{Q}$, Isler JA, Burczynski ME, et al. Comparison of the pharmacokinetics of venlafaxine extended release and desvenlafaxine in extensive and poor cytochrome P450 2D6 metabolizers. J Clin Psychopharmacol 2009;29:39-43.

10. Demartini B, Goeta D, Gambini O. A case of functional dystonia: clinical cues to differentiate between organic and functional dystonia. Neurol Sci 2019;40:1071-2 .

11. Edwards IR, Biriell C. Harmonisation in pharmacovigilance. Drug Saf 1994;10:93-102.

12. Ozen ME, Orum MH, Kalenderoglu A. Difficult patient in psychiatry practice: A case-control study. Adıyaman Üni Sağlık Bilimleri Derg 2018;4: 1064-73.

13. Herbeck DM, Fitek DJ, Svikis DS, Montoya ID, Marcus SC, West JC. Treatment compliance in patients with comorbid psychiatric and substance use disorders. Am J Addict 2005;14:195-207.

14. Örüm $M H$, Kara $M Z$, Kuştepe A, Kalenderoğlu A. Bilişsel hatalar ve dikkat-eksikliği hiperaktivite bozukluğu belirtilerinin madde kullanım özellikleri ile ilişkisi. Bağımlılık Dergisi 2019;20:47-60.

15. Ozen ME, Orum MH, Kalenderoglu A. The burden of schizophrenia on caregivers. Psychiatry and Behavioral Sciences 2018;8:105-10. 